\title{
PENGARUH INSENTIF KEUANGAN, KOMITMEN KARYAWAN, SELF EFFICACY, DAN SELF ESTEEM TERHADAP KINERJA DALAM KONDISI FAIRNESS
}

\author{
Etti Ernita Sembiring* \\ Jurusan Akuntansi Politeknik Negeri Bandung \\ *e-mail:etti.ernita@polban.ac.id
}

DiPublikasi: 01/07/2021

https://doi.org/10.22225/kr.13.1.2021.96-104

\begin{abstract}
The purpose of this research is to examine the effect of financial incentives, employee commitment, self-efficacy, and self-esteem on performance, in conditions of a sense of injustice and empirically extended that intrinsic motivation provides a larger influence on performance than extrinsic motivation in the emergence of the conditions of injustice. This study applies accounting students of Bandung State Polytechnic as research subjects and the final sample of research accordance with the research objective of 39 samples. The analytical tool used in the research is multiple regression analysis. The result showed that financial incentives have a significant effect on performance despite a sense of injustice. This shows that financial incentives remain as a strong motivation for someone to improve performance. Employee commitment, self-efficacy, and self-esteem do not significantly influence performance in a sense of injustice. Employee commitment and self-efficacy variables have negative influence direction, which means that employees are highly committed and have high self-efficacy if they have a perception of injustice towards financial incentives given as rewards for performance, then their performance will decrease. Financial incentives have a greater influence on performance compared to employee commitment, self-efficacy, and self-esteem in conditions of emerging perceptions of injustice
\end{abstract}

Keywords: financial incentives, employee commitment, self esteem, self efficacy, performance

\begin{abstract}
Abstrak
Tujuan penelitian ini adalah untuk menguji pengaruh insentif keuangan, komitmen karyawan, self efficacy dan self esteem terhadap kinerja karyawan dalam kondisi munculnya rasa ketidakadilan dan membuktikan secara empiris bahwa motivasi intrinsik memberikan pengaruh lebih besar terhadap kinerja dibandingkan motivasi ekstrinsik dalam kondisi munculnya ketidakadilan. Penelitian ini menggunakan mahasiswa Akuntansi sebagai subyek penelitian dan sampel akhir penelitian yang sesuai dengan tujuan penelitian sebanyak 39 sampel. Alat analisis yang digunakan yaitu analisis regresi berganda dengan bantuan SPSS. Hasil penelitian menunjukkan insentif keuangan berpengaruh secara signifikan terhadap kinerja meskipun muncul rasa ketidakadilan. Hal ini menunjukkan insentif keuangan masih merupakan motivasi kuat bagi seseorang untuk meningkatkan kinerja. Komitmen karyawan, self efficacy dan self esteem tidak berpengaruh secara signifikan terhadap kinerja dalam kondisi munculnya rasa ketidakadilan. Variabel komitmen karyawan dan self efficacy memiliki arah pengaruh negatif yang artinya karyawan berkomitmen tinggi dan memiliki self efficacy tinggi jika memiliki persepsi ketidakadilan terhadap insentif keuangan yang diberikan sebagai reward atas kinerja maka kinerja mereka akan turun. Insentif keuangan lebih besar pengaruhnya terhadap kinerja dibandingkan komitmen karyawan, self efficacy dan self esteem dalam kondisi munculnya persepsi ketidakadilan.
\end{abstract}

Kata Kunci : insentif keuangan, komitmen karyawan, self esteem, self efficacy, kinerja

\section{PENDAHULUAN}

Insentif keuangan merupakan salah satu faktor yang dapat memotivasi seseorang mengeluarkan kemampuan menyelesaikan pekerjaan secara maksimal. (Taylor, 2017)mengklaim bahwa uang adalah motivator terbaik. Pemberian uang sebagai insentif akan mempengaruhi kinerja dan kepuasaan kerja karyawan (Njoroge, S. W., Kwasira, J., Wambui Njoroge, S., \& Kwasira, 2015); (Rahman et al., 2016); (Mabaso \& Dlamini, 2017); (Meliana, 2017); (Jean et al., 2017); (Krishnan et al., 2018); (Etti Ernita Sembiring, 2019). Namun hal ini tidak selamanya terjadi, ada saatnya insentif keuangan tidak berpengaruh signifikan terhadap kinerja, komitmen dan kepuasan kerja (Akter, 2016), bahkan insentif berhubungan negatif dengan kinerja (Hameed et al., 2014). Meskipun beberapa hasil 
penelitian mengungkapkan insentif keuangan tidak dapat meningkatkan kinerja namun pada praktiknya terdapat perusahaan yang menggunakan uang untuk memotivasi karyawan mereka. Namun yang terjadi adalah perusahaan sulit menyelaraskan tujuan individu karyawan dengan tujuan perusahaan. Hal ini menunjukkan pemberian insentif keuangan tidak selalu menjadi motivasi karyawan untuk meningkatkan kinerja mereka. Pemberian insentif keuangan harus dilakukan secara hati-hati. (Zobal, 1999) mengungkapkan jika pemberian motivasi ekstrinsik dilakukan dengan salah maka fokus karyawan hanya pada keuntungan keuangan. Selain itu, pemberian rewards keuangan memberikan dampak negative terhadap karyawan yang tidak dapat mencapai target atau tujuan seperti hilangnya rasa percaya diri dan demotivasi. Hasil penelitian (Details \& Abdalla Moh, 2018) menunjukkan adanya hubungan yang signifikan antara sistem pemberian insentif yang efektif dengan kinerja karyawan. Oleh sebab itu pihak manajemen harus berhati-hati dalam mengambil keputusan terkait cara meningkatkan produktivitas sumber daya manusia yang merupakan aset berharga bagi perusahaan. Jangan sampai perusahaan mengeluarkan biaya besar tanpa adanya hasil yang sesuai dengan diharapkan.

Ketidakberhasilan insentif keuangan dalam

\section{TINJAUAN PUSTAKA}

Pengaruh insentif keuangan terhadap kinerja dalam kondisi rasa ketidakadilan (fairness).

Beberapa hasil penelitian menunjukkan insentif keuangan mempengaruhi kinerja. Hal ini dikarenakan pemberian reward insentif keuangan merupakan bentuk penghargaan yang diberikan atasan kepada bawahan atas apa yang mereka capai. (Mabaso \& Dlamini, 2017) melakukan penelitian dengan menguji pengaruh kompensasi terhadap kepuasan kerja karyawan. Penelitian ini melakukan survei terhadap 279 staf akademik dan hasil penelitian menunjukkan kompensasi berpengaruh signifikan terhadap kepuasan kerja karyawan. (Njoroge, S. W., Kwasira, J., Wambui Njoroge, S., \& Kwasira, 2015)melakukan penelitian mengenai pengaruh kompensasi dan reward terhadap kinerja pegawai pemerintah di Nakuru. Metoda pengumpulan data yang digunakan adalah dengan melakukan survei terhadap pegawai pemerintah Nakuru. Hasil penelitian menunjukkan adanya hubungan yang kuat antara kompensasi dan memotivasi karyawan membuat pihak manajemen berpikir mengenai faktor lain yang dapat mempengaruhi kinerja mereka. Faktor tersebut adalah motivasi intrinsik. Beberapa penelitian justru menemukan bahwa motivasi intrinsik jauh lebih mempengaruhi kinerja pegawai dibandingkan faktor ekstrinsik. (Mundhra \& Jacob, 2011) menyatakan perilaku yang muncul karena motivasi ekstrinsik hanya bersifat sementara.

Penelitian ini bertujuan untuk menguji pengaruh faktor ekstrinsik yaitu insentif keuangan dan faktor intrinsik yaitu komitmen organisasi, self efficacy dan self esteem terhadap kinerja dalam kondisi munculnya kondisi fairness (rasa ketidakadilan). Kondisi fairness yang diteliti yaitu kondisi seorang karyawan merasa adanya ketidakadilan atas insentif keuangan yang diberikan. Adanya perasaan ketidakadilan dapat menyebabkan perasaan bersalah atau tidak puas. Jika seseorang merasa kompensasi yang dia terima melebihi kompensasi yang diterima oleh teman sejawatnya dengan input yang sama maka perasaan bersalah akan muncul. Namun jika yang terjadi sebaliknya maka yang muncul adalah ketidakpuasan (Conger \& Kanungo, 1994). Diharapkan hasil penelitian ini dapat menjadi salah satu masukan empiris bagi pihak manajemen dalam mendesain sistim insentif bagi karyawannya.

reward terhadap kinerja pegawai. Namun tidak selamanya pemberian reward berupa insentif keuangan dapat mempengaruhi kinerja karyawan terutama jika muncul persepsi ketidakadilan. Teori keadilan (Adam, 1965) menjelaskan bagaimana individu terpuaskan atau tidak terpuaskan terhadap suatu kompensasi. Esensi dari teori keadilan distributif adalah mengacu pada persepsi mengenai keadilan rewards yang mereka peroleh dibandingkan input yang mereka keluarkan. Karyawan akan merasa tidak puas dan kecewa terhadap sistem pemberian insentif yang diterapkan oleh perusahaan jika saat mereka membandingkan antara reward yang diberikan dengan input yang dikeluarkan atau membandingkan antara reward yang mereka terima dengan reward yang diterima teman sejawatnya yang memberikan input yang sama adalah tidak adil. Dampak yang terjadi ialah pemberian insentif keuangan bukan meningkatkan kinerja karyawan namun malah menurunkan kinerja karyawan. (Wickramasinghe \& Dabere, 
2012) menyatakan desain dan implementasi skema insentif yang baik memiliki pengaruh positif terhadap kinerja. Hipotesis yang dapat disusun:

$\mathrm{H}_{1}$ : Insentif keuangan berpengaruh negatif secara signifikan terhadap kinerja dalam kondisi munculnya rasa ketidakadilan (fairness)

Pengaruh komitmen karyawan terhadap kinerja dalam kondisi rasa ketidakadilan (fairness).

Karyawan yang memiliki komitmen tinggi terhadap perusahaan akan melakukan tugas mereka dengan hati yang bahagia. Mereka akan berusaha seoptimal mungkin agar tujuan perusahaan tercapai. Komitmen awal yang muncul dalam diri karyawan akan berangsur angsur selaras dengan tujuan dan nilai perusahaan. Penelitian mengenai bagaimana pengaruh komitmen karyawan terhadap kinerja sudah banyak dilakukan. Hasil penelitian (Dinku, 2018), (Princy \& Rebeka, 2019) mengungkapkan komitmen karyawan berpengaruh terhadap kinerja organisasi. Namun (Sutanto E, 1999) mengungkapkan komitmen karyawan terhadap atasannya jauh lebih bernilai dibandingkan komitmen karyawan terhadap organisasi atau perusahaan. Internalisasi nilai atasan dan organisasi memiliki peran penting dalam meningkatkan kinerja organisasi. Komitmen karyawan yang tinggi terhadap atasan maupun organisasi tidak akan menurunkan kinerja mereka meskipun muncul kondisi fairness. Hal ini dikarenakan nilai yang tertanam dalam diri karyawan dan komitmen mereka untuk tetap melakukan yang terbaik bagi perusahaan. Hipotesis yang dapat disusun:

$\mathrm{H}_{2}$ : Komitmen karyawan berpengaruh positif secara signifikan terhadap kinerja dalam kondisi munculnya rasa ketidakadilan (fairness)

\section{Pengaruh self efficacy terhadap kinerja dalam}

\section{kondisi rasa ketidakadilan (fairness)}

Self efficacy adalah persepsi seseorang mengenai kemampuan mereka dalam melaksanakan tugas. (Machmud, 2018) menemukan bahwa self efficacy mempengaruhi kepuasan dan kinerja tugas. Karyawan yang memiliki self efficacy tinggi akan meningkatkan kepercayaan diri mereka dalam mencapai tujuan atau target tugas yang diberikan. Karyawan yang memiliki self efficacy yang tinggi akan memiliki kinerja yang baik meskipun dalam kondisi munculnya fairness. Hal ini dikarenakan adanya persepsi untuk membuktikan kemampuan mereka kepada orang lain sebagai bentuk penghargaan terhadap kemampuan diri sendiri. Hipotesis yang dapat disusun :

$\mathrm{H}_{3}$ : Self efficacy berpengaruh positif secara signifikan terhadap kinerja dalam kondisi munculnya rasa ketidakadilan (fairness)

\section{Pengaruh self esteem terhadap kinerja dalam}

\section{kondisi rasa ketidakadilan (fairness).}

Self esteem merupakan persepsi seseorang mengenai dirinya sendiri. Seberapa besar seseorang itu menghargai diri sendiri. Hasil penelitian (Akgunduz, 2015) menunjukkan self esteem berhubungan positif dengan kinerja. Seseorang yang memiliki self esteem yang tinggi akan cenderung menunjukkan kinerjanya secara optimal dikarenakan kinerja yang dihasilkan merupakan suatu bentuk kebanggaan terhadap diri sendiri. Meskipun dalam kondisi fairness, seseorang yang memiliki self esteem tinggi akan tetap mempertahankan kinerjanya. Hipotesis yang disusun :

$\mathrm{H}_{4}$ : Self esteem berpengaruh positif secara signifikan terhadap kinerja dalam kondisi munculnya rasa ketidakadilan (fairness)

Hasil penelitian (Sleimi \& Davut, 2015) menunjukkan baik motivasi intrinsic maupun motivasi ekstrinsik mempengaruhi kepuasan dan kinerja karyawan. Motivasi instrinsik seperti komitmen karyawan, self efficacy dan self esteemakan lebih berpengaruh terhadap kinerja dibandingkan motivasi ekstrinsik yaitu insentif keuangan. Hal ini dikarenakan motivasi ekstrinsik hanya akan berpengaruh terhadap kinerja dalam jangka pendek sedangkan motivasi intrinsik akan mempengaruhi kinerja dalam jangka panjang. (Snelgar et al., 2017) mengungkapkan budaya memiliki peran penting dalam membentuk motivasi instrinsik. Meskipun motivasi ekstrinsik dan motivasi intrinsik sama sama berpengaruh terhadap kinerja namun pengaruhnya akan sangat berbeda jika dalam kondisi fairness. Motivasi intrinsik akan tetap berpengaruh positif terhadap kinerja. Atau dengan kata lain semakin tinggi motivasi intrinsik maka kinerja juga semakin tinggi. Ini berbanding 
terbalik dengan motivasi ekstrinsik. Pada saat muncul fairness, motivasi ekstrinsik bukan lagi berpengaruh positif terhadap kinerja namun tidak berpengaruh dan malah berpengaruh negatif terhadap kinerja. Dengan kata lain pengaruh motivasi intrinsik terhadap kinerja akan lebih besar dibandingkan motivasi ekstrinsik pada saat muncul

\section{METODE PENELITIAN}

Penelitian ini menggunakan jenis data primer dengan teknik pengumpulan data menggunakan survey dan eksperimen. Subyek penelitian adalah mahasiswa dari Jurusan Akuntansi Politeknik Negeri Bandung. Adapun rancangan penelitian dimulai dari permintaan kesediaan mahasiswa Jurusan Akuntansi Politeknik Negeri Bandung untuk mengikuti kegiatan eksperimen secara penuh. Pada tahap awal sebelum pelaksanaan eksperimen, mahasiswa diberikan kuesioner self efficacy, self esteem dan komitmen karyawan. Setelah kuesioner dikumpulkan maka tahap berikutnya adalah pelaksanaan eksperimen. Mahasiswa diminta untuk melakukan tugas produksi dan diberi manipulasi berupa informasi mengenai insentif keuangan yang diberikan. Informasi tersebut menyatakan bahwa subyek penelitian dibagi menjadi dua (2) kelompok dengan metode kompensasi (insentif keuangan) berbeda. Masing masing kelompok akan berisikan subyek penelitian yang dipilih secara acak oleh peneliti. Pada tahap manipulasi ini, subyek penelitian juga diberi informasi atau penjelasan bahwa semua subyek penelitian memiliki input yang sama dan tugas produksi yang sama. Setelah manipulasi diberikan, tahap berikutnya adalah cek manipulasi berupa pertanyaan mengenai perasaan mereka terhadap insentif keuangan yang diberikan. Pertanyaan tersebut diberi range nilai 1 sampai 10 . Langkah berikutnya adalah subyek penelitian diminta untuk latihan mengerjakan tugas produksi. Subyek penelitian diminta untuk mengubah simbol simbol menjadi huruf. Hal ini ditujukan agar subyek penelitian paham dan mampu melaksanakan tugas produksi. Tahap berikutnya adalah pelaksanaan produksi, setiap simbol yang mampu mereka kerjakan dengan benar akan dikonversi ke dalam bentuk Rupiah sebagai insentif atas kinerja mereka. Setelah pelaksanaan eksperimen selesai maka tahap berikutnya adalah tahap tabulasi data. Pada tahap tabulasi data, langkah awal yang dilakukan oleh peneliti adalah menghitung nilai fairness. Hipotesis yang disusun:

$\mathrm{H}_{5}$ : Pengaruh komitmen karyawan, self efficacy dan self esteem terhadap kinerja lebih besar dibandingkan pengaruh insentif keuangan terhadap kinerja dalam kondisi munculnya rasa ketidakadilan (fairness)

atas atau sama dengan enam (6) maka menunjukkan muncul fairness sehingga subyek tersebut dapat dijadikan sampel penelitian. Namun jika nilai responden berada di bawah enam (6) maka menunjukkan tidak muncul fairness sehingga data responden yang bersangkutan harus dihapus. Setelah dilakukan tabulasi data maka langkah berikutnya adalah melakukan analisis data. Teknik analisis data yang digunakan adalah regresi berganda. Bentuk matematis dari analisis regresi berganda yang akan dipergunakan pada penelitian ini yaitu:

$$
Y=\beta_{0}+\beta_{1} X_{1}+\beta 2 X_{2}+\beta_{3} X_{3}+\beta_{4} X_{4}+e
$$

$$
\text { Ket: } \begin{aligned}
\mathrm{Y} & =\text { kinerja } \\
\mathrm{X}_{1} & =\text { insentif keuangan } \\
\mathrm{X}_{2} & =\text { komitmen karyawan } \\
\mathrm{X}_{3} & =\text { self efficacy } \\
\mathrm{X}_{4} & =\text { self esteem }
\end{aligned}
$$

Penelitian ini menggunakan taraf signifikansi 5 $\%$. Penarikan kesimpulan yaitu :

$$
\begin{aligned}
& \text { Tk signifikansi }(\alpha)<0,05 \text {, kesimpulan } \\
& \text { Ho ditolak } \\
& \text { Tk signifikansi }(\alpha)>0,05 \text {, kesimpulan } \\
& \text { Ho diterima }
\end{aligned}
$$

Sebelum melakukan uji regresi berganda, harus dilakukan pengujian asumsi klasik yaitu (Ghozali, 2011) yaitu:

1. Uji normalitas data bertujuan untuk menguji apakah dalam model regresi, variabel terikat dan variabel bebas memiliki distribusi normal atau tidak. Untuk pengujian normalitas menggunakan metoda KolmografSmirnov $(K-S)$ dengan dasar pengambilan keputusan jika tk signifikansi $(\alpha)>0,05$ maka data berdistribusi normal dan jika tk signifikansi $(\alpha)<0,05$ maka data tidak berdistribusi normal. 
2. Uji multikolinieritas bertujuan untuk menguji apakah model regresi memiliki korelasi antar variabel bebas (independen). Untuk mendeteksi ada tidaknya multikolinieritas dapat dilihat dari nilai variance inflation factor (VIF). Apabila nilai VIF dibawah 10 maka dapat disimpulkan bahwa tidak terjadi multikolinieritas.

\section{HASIL DAN PEMBAHASAN}

Responden awal yang mengikuti eksperimen pada penelitian ini sebanyak 63 mahasiswa tingkat tiga Akuntansi. Setelah dilakukan tabulasi data, hanya 59 mahasiswa yang termasuk dalam kategori subyek penelitian yaitu responden yang merasa bahwa insentif keuangan yang diberikan tidak adil dan memunculkan persepsi fairness. Pada saat dilakukan uji normalitas dengan metoda Kolmograf-Smirnov (K-S) dapat dilihat data tidak berdistribusi normal lalu dilakukan penormalan data dengan cara $\ln$ dan abs namun data tetap belum berdistribusi normal. Berikut adalah hasil uji K-S setelah dilakukan $\ln$ dan abs data.

Tabel.1

\begin{tabular}{lcl}
\multicolumn{2}{c}{ Hasil Uji Normalitas Sebelum Data Outlier Dibuang } \\
Variabel & Asymp.Sig & \multicolumn{1}{c}{ Keterangan } \\
\hline Kinerja & 0,830 & Tidak signifikan \\
Insentif keuangan & 0,008 & Signifikan \\
Komitmen karyawan & 0,825 & Tidak signifikan \\
Self efficacy & 0,533 & Tidak signifikan \\
Self esteem & 0,601 & Tidak signifikan
\end{tabular}

Pada tabel di atas dapat dilihat variabel insentif keuangan adalah signifikan sehingga belum memenuhi asumsi normalitas. Untuk memenuhi normalitas dilakukan pembuangan data yang

bersifat outlier sehingga data akhir yang digunakan berjumlah 39. Berikut adalah uji normalitas data setelah data outlier dikeluarkan.

Tabel.2

\section{Hasil Uji Normalitas Setelah Data Outlier Dibuang}

\begin{tabular}{|lc|}
\hline \multicolumn{1}{c}{ Variabel } & Asymp.Sig \\
\hline Kinerja & 0,956 \\
\hline Insentif keuangan & 0,065 \\
Komitmen karyawan & 0,704 \\
Self efficacy & 0,747 \\
Self esteem & 0,955 \\
\hline
\end{tabular}

Pada tabel di atas dapat dilihat seluruh variabel adalah tidak signifikan karena memiliki nilai asymp.sig $>0,05$ sehingga dapat dikatakan data sudah memenuhi asumsi normalitas. Data penelitian yang dapat digunakan selanjutnya sebanyak 39 dengan rata -rata umur subyek penelitian adalah 20 tahun dan jenis kelamin seluruh responden adalah perempuan. Berikut adalah tabel statistik deskriptif variabel 


\section{Tabel.3}

\begin{tabular}{lcccc}
\multicolumn{1}{c}{ Variabel } & Nilai minimum & $\begin{array}{c}\text { Nilai } \\
\text { maksimu } \\
\text { m }\end{array}$ & Nilai rata-rata & $\begin{array}{c}\text { Nilai deviasi } \\
\text { standar }\end{array}$ \\
inerja & 29,00 & 76,00 & 51,79 & 10,55 \\
sentif Keuangan & 4000,00 & 10000,00 & 6923,07 & 1826,48 \\
omitmen karyawan & 4,44 & 9,78 & 7,92 & 1,03 \\
?lf efficacy & 4,75 & 10,00 & 7,95 & 1,02 \\
:If esteem & 4,29 & 9,43 & 7,25 & 1,16
\end{tabular}

Berdasarkan tabel di atas dapat dilihat bahwa subyek penelitian memiliki nilai komitmen karyawan, self esteem dan self efficacy yang tinggi. Hal ini dapat dilihat dari nilai rata-ratanya yaitu 7,92 untuk komitmen karyawan, 7,95 untuk self efficacy dan 7,25 untuk self esteem. Nilai ketiga variabel ini diperoleh dari nilai kuesioner yang diisi responden sebelum mereka mendapatkan manipulasi (treatment) sehingga tidak terpengaruh dengan manipulasi (treatment) yang dilakukan. Sedangkan nilai rata-rata kinerja sebesar 51,79 dan insentif keuangan sebesar 6923,07 diperoleh setelah dilakukan manipulasi (treatment).
Sebelum dilakukan uji hipotesis menggunakan uji regresi berganda dilakukan uji asumsi klasik yaitu uji normalitas dan uji multikolinieritas. Untuk uji normalitas menggunakan uji K-S data berdistribusi normal setelah beberapa data outlier dibuang, sehingga data awal yang berjumlah 59 berubah menjadi 39. Hasil uji multikolinieritas menunjukkan tidak terjadi multikolinieritas, hal ini dapat dilihat dari nilai VIF dibawah 10 maka dapat disimpulkan bahwa penelitian sudah memenuhi asumsi tidak terjadi multikolinieritas. Berikut adalah tabel hasil uji multikolinieritas

\section{Tabel.4}

Hasil uji multikolinieritas.

\begin{tabular}{|lcl|}
\hline \multicolumn{1}{|c}{ Variabel } & Nilai VIF & Keterangan \\
\hline Insentif keuangan & 1,134 & Tidak terjadi multikolinieritas \\
\hline Komitmen karyawan & 3,084 & Tidak terjadi multikolinieritas \\
Self efficacy & 2,995 & Tidak terjadi multikolinieritas \\
Self Esteem & 3,096 & Tidak terjadi multikolinieritas
\end{tabular}

Langkah berikutnya adalah dilakukannya uji statistic regresi berganda. Berikut adalah persamaan regresi yang dihasilkan :

$$
\begin{aligned}
Y & =23,796+0,005 X 1-0,437 X \\
\text { Ket }: \mathrm{Y} & =\text { kinerja } \\
\mathrm{X}_{1} & =\text { insentif keuangan } \\
\mathrm{X}_{2} & =\text { komitmen karyawan } \\
\mathrm{X}_{3} & =\text { self efficacy } \\
\mathrm{X}_{4} & =\text { self esteem }
\end{aligned}
$$

Berdasarkan persamaan regresi dapat dilihat besar dan arah hubungan variabel independen terhadap dependen pada saat muncul rasa ketidakadilan.
Variabel insentif keuangan dan self esteem memiliki arah yang positif yang artinya nilai kinerja akan semakin naik dengan meningkatnya insentif keuangan dan self esteem yang dimiliki karyawan. Berbeda dengan variabel komitmen karyawan dan self efficacy yang memiliki arah negative yaitu semakin tinggi nilai komitmen karyawan dan self efficacy mereka maka kinerja akan semakin turun pada saat karyawan merasakan adanya ketidakadilan atas insentif keuangan yang mereka terima sebagai bentuk kompensasi kinerja mereka. Berikut adalah tabel uji hipotesis: 
Tabel 5

Hasil uji hipotesis

\begin{tabular}{lc}
\multicolumn{1}{c}{ Variabel } & $\mathrm{p}-$ Value \\
\hline Insentif keuangan & 0,000 \\
Komitmen karyawan & 0,820 \\
Self efficacy & 0,650 \\
Self Esteem & 0,592 \\
Adj $R^{2}$ var. insentif keuangan & 0,609 \\
Adj $R^{2}$ var. komitmen karyawan, 0,060 \\
self efficacy, self esteem
\end{tabular}

Berdasarkan hasil uji statistik diketahui hipotesis satu diterima yaitu insentif keuangan berpengaruh secara signifikan terhadap kinerja dalam kondisi munculnya rasa ketidakadilan namun arah pengaruh tidak sesuai dengan hipotesis yang disusun. Hipotesis yang disusun menyatakan insentif keuangan akan berpengaruh negatif terhadap kinerja dalam kondisi munculnya rasa ketidakadilan (fairness) namun hasil uji menunjukkan arah positif. Hal ini menunjukkan insentif keuangan masih merupakan faktor motivasi yang kuat untuk meningkatkan kinerja karyawan. Hipotesis dua, tiga, empat dan lima ditolak. Komitmen karyawan, self efficacy dan self esteem tidak berpengaruh secara signifikan terhadap kinerja dalam kondisi munculnya rasa ketidakadilan. Apabila dilihat dari persamaan regresi, ketiga variabel tersebut memiliki arah yang berbeda. Variabel komitmen karyawan dan self efficacy memiliki arah yang negatif sedangkan self esteem memiliki arah yang positif. Hal ini menunjukkan komitmen karyawan dan self efficacy yang tinggi dapat menurunkan kinerja karyawan jika muncul perasaan adanya ketidakadilan meskipun pengaruh ini tidak signifikan. Jika pada awalnya karyawan berkomitmen tinggi terhadap perusahaan akan melaksanakan tugas mereka dengan sebaik-baiknya dan seoptimal mungkin menyelaraskan tujuan pribadi dengan tujuan dan nilai perusahaan namun yang terjadi adalah sebaliknya jika karyawan merasakan ketidakadilan, komitmen karyawan yang tinggi justru akan menurunkan kinerja mereka karena perasaan ketidakpuasan terhadap perusahaan. Begitu juga dengan self efficacy, karyawan yang memiliki self efficacy tinggi memiliki rasa percaya diri yang tinggi terhadap kemampuan mereka dalam melaksanakan tugas sehingga pada saat muncul perasaan ketidakadilan maka akan muncul persepsi perusahaan tidak menghargai kemampuan yang dimiliki oleh karyawan. Hal ini dapat mengakibatkan penurunan kinerja karyawan.

Berdasarkan nilai adjusted $R$ square diketahui pengaruh insentif keuangan terhadap kinerja adalah sebesar 0,609 yang artinya insentif keuangan memiliki pengaruh sebesar $60,9 \%$ terhadap kinerja sedangkan variabel komitmen karyawan, self efficacy dan self esteem memiliki nilai adjusted $R$ square 0,060 yang yang artinya komitmen karyawan, self efficacy dan self esteem hanya memiliki pengaruh sebesar $6 \%$ terhadap kinerja dalam kondisi munculnya rasa ketidakadilan (fairness). Hasil ini menunjukkan hipotesis yang menyatakan pengaruh komitmen karyawan, self efficacy dan self esteem terhadap kinerja lebih besar dibandingkan pengaruh insentif keuangan terhadap kinerja dalam kondisi munculnya rasa ketidakadilan (fairness) tidak dapat didukung.

\section{KESIMPULAN DAN SARAN}

Insentif keuangan berpengaruh secara signifikan terhadap kinerja meskipun muncul rasa ketidakadilan. Hasil ini menunjukkan insentif keuangan masih menjadi motivasi kuat bagi seseorang untuk meningkatkan kinerja mereka. Meskipun insentif keuangan berpengaruh secara signifikan terhadap kinerja namun arah pengaruh tidak mendukung hipotesis vano diaiukan.

Hipotesis yang disusun menyatakan insentif keuangan berpengaruh negatif secara signifikan terhadap kinerja jika muncul rasa fairness pada karyawan namun hasil penelitian justru membuktikan insentif keuangan berpengaruh positif secara signifikan terhadap kinerja meskipun muncul rasa fairness pada karyawan. Meskipun demikian pihak manaiemen harus tetan berhati hati 
dalam mendesain kompensasi yang akan diberikan kepada karyawan. Seperti yang dinyatakan oleh (Mundhra \& Jacob, 2011) yaitu perilaku yang muncul karena motivasi ekstrinsik hanya bersifat sementara. Dengan kata lain jangan sampai insentif sebagai reward yang diberikan oleh atasan kepada bawahan hanya akan meningkatkan kinerja karyawan dalam jangka pendek dan tidak akan berfungsi untuk jangka panjang sehingga pemberian insentif akan menjadi hal yang sia-sia. Komitmen karyawan, self efficacy dan self esteem tidak berpengaruh secara signifikan terhadap kinerja dalam kondisi munculnya rasa ketidakadilan. Komitmen karyawan dan self efficacy memiliki arah pengaruh negatif yang artinya karyawan berkomitmen tinggi dan memiliki

\section{DAFTAR PUSTAKA}

Adam, J. S. (1965). Inequity in social exchanges. In Advances in Experimental Social Psychology.

Akgunduz, Y. (2015). The influence of self-esteem and role stress on job performance in hotel businesses. International Journal of Contemporary Hospitality Management. https://doi.org/10.1108/IJCHM-09-20130421

Akter, N. (2016). Employee Training and Employee Development Is the Predictors of Employee Performance; A Study on Garments Manufacturing Sector In Bangladesh. IOSR Journal of Business and Management.

Conger, J. A., \& Kanungo, R. N. (1994). Charismatic leadership in organizations: Perceived behavioral attributes and their measurement. Journal of Organizational

Behavior. https://doi.org/10.1002/job.4030150508

Details, A., \& Abdalla Moh, D. (2018). Impact of Financial Incentives on Performance of Employees in Jordanian Commercial Banks and its Reflections on Jordanian Economy: A Field Study. In International Journal of Management Sciences and Business Research.

Dinku, G. T. (2018). Effects of employees commitment on organizational performance at Arjo Didessa Sugar Factory. African Journal of Business Management. https://doi.org/10.5897/ajbm2017.8395

Etti Ernita Sembiring. (2019). Pengaruh Insentif Keuangan Terhadap Kinerja Dengan Keadilan Distributif Sebagai Variabel Pemoderasi: Suatu Eksperimen. Jurnal Akuntansi Keuangan Dan Bisnis, Vol.12 No., 87-94.

Ghozali, I. (2011). Aplikasi Analisis Multivariate Dengan Program IBM SPSS 19 (edisi kelima). In Aplikasi Analisis Multivariate dengan program SPSS.

Hameed, M. A., Ramzan, M., Kashif Zubair, H., Ali, G., \& Arslan, M. (2014). Impact of Compensation on Employee Performance (Empirical Evidence from Banking Sector of Pakistan). International Journal of Business and Social Science.

Jean, K. N., Ngui, T. K., \& Robert, A. (2017). Effect of Compensation Strategies on Employee Performance: A self efficacy tinggi jika memiliki persepsi ketidakadilan terhadap insentif keuangan yang diberikan sebagai reward atas kinerja mereka maka kinerja mereka akan turun. Hal ini dimungkinkan karena munculnya rasa kecewa terhadap perusahaan yang dianggap kurang menghargai kemampuan dan komitmen karyawan terhadap perusahaan. Apabila dilihat dari nilai adjusted $R$ Square, insentif keuangan memiliki pengaruh yang lebih besar terhadap kinerja dibandingkan komitmen karyawan, self efficacy dan self esteem dalam kondisi munculnya persepsi ketidakadilan.

Saran bagi penelitian selanjutnya yaitu dapat menggunakan skema insentif keuangan fixed rate dengan informasi asimetri sebagai variabel pemoderasi.

Case Study of Mombasa Cement Limited. International Journal of Innovative Social Sciences \& Humanities Research.

Krishnan, R., Loon, K. W., Ahmad, N. A. F. binti, \& Yunus, N. A. S. (2018). Examining the Relationship between Organizational Justice and Job Performance. International Journal of Academic Research in Business and Social Sciences. https://doi.org/10.6007/ijarbss/v8i3/3942

Mabaso, C. M., \& Dlamini, B. I. (2017). Impact of Compensation and Benefits on Job Satisfaction. Research Journal of Business Management. https://doi.org/10.3923/rjbm.2017.80.90

Machmud, S. (2018). The Influence of Self-Efficacy on Satisfaction and Work-Related Performance. INTERNATIONAL JOURNAL OF MANAGEMENT SCIENCE AND BUSINESS ADMINISTRATION. https://doi.org/10.18775/ijmsba.1849-56645419.2014.44.1005

Meliana, V. (2017). EFEKTIVITAS PEMBERIAN KOMPENSASI FINANSIAL PERUSAHAAN. Jurnal Riset Manajemen Dan Bisnis (JRMB) Fakultas Ekonomi UNIAT. https://doi.org/10.36226/jrmb.v2i3.67

Mundhra, D. Das, \& Jacob, W. (2011). Intrinsic Motivators in the Indian Manufacturing Sector: An Empirical Study. The IUP Journal of Organizational Behavior.

Njoroge, S. W., Kwasira, J., Wambui Njoroge, S., \& Kwasira, J. (2015). Influence of Compensation and Reward on Performance of Employees at Nakuru County Government. IOSR Journal of Business and ManagementVer. https://doi.org/https://doi.org/10.9790/487X-171118793

Princy, K., \& Rebeka, E. (2019). Employee commitment on organizational performance. International Journal of Recent Technology and Engineering. https://doi.org/10.35940/ijrte.C4078.098319

Rahman, A., Shahzad, N., Mustafa, K., Khan, M. F., \& Qurashi, F. (2016). Effects of organizational justice on organizational commitment. International Journal of Economics and Financial Issues. 
Sleimi, M. T., \& Davut, S. (2015). Intrinsic and Extrinsic Motivation: Pivotal Role in Bank Tellers Satisfaction and Performance: Case Study of Palestinian Local Banks. International Journal of Business and Social Science.

Snelgar, R., Shelton, S. A., \& Giesser, A. (2017). A comparison of South African and German extrinsic and intrinsic motivation. South African Journal of Economic and Management

Sciences. https://doi.org/10.4102/sajems.v20i1.1552

Sutanto E, M. (1999). The Relationship Between Employee Commitment and Job Performance. Jurnal Manajemen Dan Kewirausahaan, Vol.1 No.1(Vol.1 No.1 March 1999).

Taylor, F. W. (2017). The Principles of Scientific Management. In Modern Economic Classics-Evaluations Through
Time.

https://doi.org/https://doi.org/10.4324/978131527054822

Wickramasinghe, V., \& Dabere, S. (2012). Effects of performance-based financial incentives on work performance: A study of technical-level employees in the private sector in Sri Lanka. Performance Improvement Quarterly. https://doi.org/10.1002/piq.21121

Zobal, C. (1999). The "ideal" team compensation system - an overview, part II. Team Performance Management: An International

Journal. 